\title{
WestVirginiaUniversity
}

THE RESEARCH REPOSITORY @ WVU

Volume 45 | Issue 3

Article 10

April 1939

\section{The Licensing of Professions in West Virginia}

Julius Cohen

West Virginia University

Follow this and additional works at: https://researchrepository.wvu.edu/wvlr

Part of the Labor and Employment Law Commons, and the State and Local Government Law Commons

Recommended Citation

Julius Cohen, The Licensing of Professions in West Virginia, 45 W. Va. L. Rev. (1939).

Available at: https://researchrepository.wvu.edu/wvlr/vol45/iss3/10

This Book Review is brought to you for free and open access by the WVU College of Law at The Research Repository @ WVU. It has been accepted for inclusion in West Virginia Law Review by an authorized editor of The Research Repository @WVU. For more information, please contact ian.harmon@mail.wvu.edu. 


\section{BOOK REVIEWS}

The Licensing of Professions in West Virainia. By Frances Priscilla De Lancy. Chicago, IIl. The Foundation Press. 1938. Pp. 187.

The unique offensive launched by the Department of Justice against the American Medical Association has focused public attention upon one facet of a large problem - the relation between government and the professions. The subject has received considerable attention in England, ${ }^{1}$ but has been greatly neglected in this country, even though the added complexity of a federal structure would seem to make the problem more inviting. The little that has been done in this field in the United States has served merely to introduce the problems involved. ${ }^{2}$ Intensive studies in the various state jurisdictions have been grievously lacking. Dr. De Lancy's study is thus welcome, not only because it is timely, but because it may serve as a needed impetus for similar studies elsewhere.

To prepare the groundwork for what is to follow, the first chapter of Dr. De Lancy's work tackles the question "What is a profession?", and arrives at the conclusion that an air-tight classification is impossible. What is to be emphasized? The nature of the service? The educational background? Competence? The amount of pay? Acknowledging the arbitrariness of any "complete" classification, Dr. De Lancy selects the commonly accepted porfessions for study, e.g., the medical arts and related fields, law, accounting and the building arts.

In the second chapter the author has written a short history of professional licensure in West Virginia, pointing out, among other things, that it was not until 1880 that the professional associations were able to convince the legislature that the state should use its power to license those in the professions. It is shown that the historical pattern of licensing in the medical profession is repeated in the other professional fields-the system by which licenses were granted to graduates as well as nongraduates who met other tests of competency; the period of wholesale corruption in which diplomas were sold in the open market; the tightening de-

\footnotetext{
1 See, for example, Carr-Saunders \& Wilson, The Profresstons (1933); Beatrice \& Sidney Webb, Special Supplement on Professional Associations, 9 The New Stateswa 1-48.

2 For instance, Freund, Administrative Powers Over Persons aNd PROPERTY (1928) $429-436$.
} 
mand for academic training; and the movement away from ad hoc political boards.

In the chapter on "Present Licensing Provisions" the author discusses the administrative standards which guide the issuance of licenses; reciprocity provisions; and the question of discipline. Placed a bit out of context in the chapter is an analysis of the constitutional issues underlying the problem of licensure, with particular emphasis upon the conflict between the police power and the due process clause. Chapter four deals with the administration of licenses. Of special interest is the analysis of the powers of $a d$ hoc boards, and the restraints upon their power in terms of procedural guarantees of notice and hearing, reviewability, etc. In this field the reviewability of administrative action by judicial tribunals does not play the important role that it does in the case of rate determination by administrative bodies. ${ }^{3}$ It is pointed out that uniformity of administrative procedure in licensing professions has been partially achieved by the states in looking to the national associations of the professional groups for guidance.

The concluding chapter describes the trend in professional licensure as being towards the guild theory of control, but as being tempered by current consideration of socialistic ideology. The author, however, believes that the encroachment of socialistic ideology is too weak to offer substantial resistance to the power of the professional associations.

Not to mention the attractive graphs and tables, the author has spared no effort in collecting an extensive bibliography on the subject. It is hoped that Dr. De Lancy will continue to develop the implications of the materials she presents, and will be urged on by her remarks in the preface that the "approaching professional guild control may have some significance for the whole field of political science."

West Virginia University, Juturs CoHEN. Morgantown, West Virginia.

Jurispruderce. By Francis P. LeBuffe and James V. Hayes. New York. Fordham University Press, 1924, 1938. Pp. xxiii, 286.

Essentially a development of one topic, - analytical jurisprudence, - this revision of the work as originally issued covers

s See, e. g., Ohio Valley Water Co. v. Ben Avon Borough, 253 U. S. 287, 40 S. Ct, 527, 64 L, Ed, 908 (1920). 